\title{
Between Signing and Ratifying: Preratification Politics, the Disability Convention, and the Dutch
}

\author{
Barbara Oomen* \\ Was published as Oomen, Barbara (2018), 'Between Signing and Ratifying: Preratification \\ Politics, the Disability Convention, and the Dutch', Human Rights Quarterly, 40 (2), 420 - \\ 46.
}

\begin{abstract}
The ever-increasing scholarship on the politics of human rights focuses on either international treaty negotiations or domestic politics after ratification. It thus misses how the stage of implementation is often crucially set in the period between signing and ratifying. This article addresses this lacuna via an in-depth discussion of the ratification process of the Disability Convention (CRPD) in the Netherlands. In this period, stakeholders highlight certain treaty obligations, while downplaying or ignoring others. This theory of preratification politics calls for more differentiation between treaty obligations and attention to the politics of their mobilization, even in the most monist countries.
\end{abstract}

\section{Introduction}

The 2016 Hansard of the Netherlands shows one remarkable insertion. Its rendition of the parliamentary debate on the ratification of the UN Convention on the Rights of Persons with Disabilities (CRPD), in italics, indicates that, at some point during the debate, instead of applause, some dog barking took place. ${ }^{1}$ This is not only an indication of the fact that during the discussion, for the first time, assistance dogs had been allowed to enter the public gallery; it also serves to illustrate how one specific aspect of the treaty objectives-accessibility for those reliant on assistance dogs-became highlighted in the Dutch parliamentary debate, whereas other elements of the Treaty were downplayed or downright ignored in the nine years it took the Dutch to ratify the CRPD. ${ }^{2}$

What happened in these nine years, and what happens more generally in the period between States signing and ratifying treaties, deserves further scrutiny than has been awarded by scholars to date. The past decades have led to an explosion of literature on how international human rights acquire meaning in a given local context, whether under the heading of "enforcement," "mobilization," "compliance," "effectiveness," "socialization," or elsewise. ${ }^{3}$ The bulk of this literature, however, considers either what happens during international treaty negotiations or after ratification. ${ }^{4}$ This is a significant omission. Preratification politics can, theoretically, have a crucial impact on the way in which human rights treaties, and their specific provisions, are understood, mobilized, enforced and-ultimately-acquire meaning in a given setting. The average three years and ten months it takes those countries who do ratify a human rights treaty to do so often constitutes a period of intense domestic negotiations. In this time, the treaty obligations agreed upon internationally are introduced into the domestic setting, with key actors like those within the state, but also NGOs, political parties, the media, academia, and interested individuals seeking to highlight, downplay, or simply ignore certain treaty obligations before the human rights treaty moves to the phase of actual enforcement. ${ }^{5}$ 
Academic attention for preratification politics seems all the more important where it concerns special human rights treaties. Such treaties often do not create new rights, but serve to raise awareness and further institutionalize the preexisting rights of particular groups, like women (CEDAW), migrant workers (ICMW), and children (CRC). Their essential purpose is thus political: reemphasizing the fact that the group concerned and the individuals involved also have human rights, and ensuring that these rights are respected. Special treaties, arguably more than others, "reflect politics but . . . also shape political behavior, setting the stage for new political alliances, empowering new political actors, and heightening public scrutiny."6 Frédéric Mégret, for instance, after a thoughtful analysis of the rationale for a special treaty like the CRPD, concludes that " $[\mathrm{t}]$ he Convention is testimony to the significant need for specific human rights instruments when it comes to certain categories of humanity whose condition has made them uniquely vulnerable to human rights violations and who are insufficiently protected by the existing, mainstream vocabulary of rights."7 As the fourth UN Convention to address a particular group, the CRPD is also interesting because it incorporates many recent insights on what constitutes effective mechanisms of treaty implementation. ${ }^{8}$

Against this background, this article seeks to analyze and theorize preratification politics based on a case study of the processes between the Dutch signing of the CRPD and its ratification, in order to further our understanding of how human rights acquire meaning in a given setting. What were the politics surrounding the process towards CRPD ratification in the Netherlands, and what do these teach us about the politics of this particular phase of human rights implementation in general? These questions are answered based on an analysis of the relevant legal, policy, and media documentation, including the social media that are so important in human rights activism these days, analyzed via the qualitative data-analysis software Nvivo based on a grounded theory approach. ${ }^{9}$ In addition, interviews with key stakeholders took place, as well as a digital focus group discussion and research survey amongst the population at large and those most directly affected by the objectives of the Disability Convention.

The basis for a theory of preratification politics is formed via an overview of recent literature on the politics of human rights implementation and the actors and processes involved in it. Subsequently, this article discusses the objectives of the CRPD, its inbuilt conceptions on treaty implementation, and the general way in which the Netherlands related to the CRPD before and after signing the treaty in 2007. The Dutch instance shows how key actors have three post signature approaches specific to treaty obligations: highlighting, downplaying, or simply ignoring them. . A discussion of these three strategies, on the basis of specific examples, leads to a conclusion on the wider implications of the case of the Disability Convention and the Dutch. In addition, this article offers research on how the period before ratification of key human rights treaties sets the stage for their implementation and demonstrates the importance of scholarly attention for these processes..

\section{The Politics of Human Rights Implementation}

The way in which human rights treaties acquire meaning in a given national or local setting has become subject to a great deal of socio-scientific research over the past decades. As Gregory Shaffer and Tom Ginsburg argued, "[t]he theoretical debate over whether international law matters is a stale one. What matters now is the study of the conditions under which international law is formed and has effects." 10 Here, political scientists have sunk their teeth into the reasons for state compliance with human rights treaties, the variables that account for it, and the

mechanisms by which it takes place. One key division is between rationalist approaches - that 
focus on the trade-off that states see between compliance and non-compliance-and the more constructivist approaches - that emphasize the way in which various actors, their interests, and normative power shape both international and national processes of treaty compliance. ${ }^{11}$ Ryan Goodman and Derek Jinks, for instance, argue that next to material inducement and persuasion, processes of acculturation lead to treaty compliance. ${ }^{12}$

One common denominator in this literature is the importance granted to specific actors in treaty implementation. Without a domestic constituency committed towards mobilizing the treaty obligations, little happens. ${ }^{13}$ Human rights, as Beth Simmons put it, "are highly contingent on the nature of domestic demands, institutions, and capacities." 14 In the early days of political science research on the topic, Thomas Risse set out how the interplay between local and international NGOs can pressure governments into compliance with human rights obligations. ${ }^{15}$ These days, however, one must take into account the multi-layered nature of formal human rights obligations. Human rights are increasingly defined and given meaning at the regional level, for instance, in the context of Council of Europe's European Convention on Human Rights, and in that of the European Union. Similarly, municipalities and regions also increasingly claim a formal role in human rights implementation, for instance, via adopting an identity as human rights cities. ${ }^{16}$ This interplay between the international, regional, national, and local levels leads to a constitutional pluralism in the formal legal sense and different interpretations of the normative content of specific rights are mobilized and influence each other. ${ }^{17}$

Concerning non-state actors, there is a widespread consensus on the key role of NGOs in both bringing about human rights treaties and mobilizing them domestically. NGOs are the most important enforcement mechanisms in the field of human rights, pressuring states towards treaty formulation, ratification, reporting, and ultimately compliance. ${ }^{18}$ Here, the differences between NGOs should be noted: some are better funded and more vocal than others, thus ensuring more attention for their issues of concern. ${ }^{19}$ Research also shows the role of businesses, churches, other organizations, and differing political parties in domestic processes of treaty implementation. ${ }^{20}$ Of course, the judiciary plays a key role in forcing governments to comply with treaty obligations - initially in specific situations, but often with much wider impact. ${ }^{21}$ Likewise, media attention plays an important role in drawing attention to the treaty obligations and their consequences. Increasingly, international monitoring mechanisms play a role in enhancing domestic implementation. ${ }^{22}$ Less scholarly attention is paid to the role of individuals, even if there is ample evidence of the impact that one person, who subsequently mobilizes other actors, can have. ${ }^{23}$

The mechanisms of human rights implementation have been defined as the "meso-level processes and their constitutive elements that can produce (or prevent) social transformation." 24 Classical legal mechanisms are legislative enactment, policy measures, judicial enforcement, and the exertion of soft power via treaty monitoring bodies-by means of treaty reporting and individual communications. ${ }^{25}$ Social science scholars show the potential impact of these mechanisms is closely related to the relationship that they have wider political processes. The impact human rights litigation has, for instance, is heightened by NGO pressure, just like the Concluding Observations of treaty bodies have more effect when they are mobilized by civil society and referred to in the media..${ }^{26}$ Other key mechanisms are awareness of treaty obligations amongst key stakeholders and the media: "treaties need a strong domestic constituency to have local impact." 27 Over the past decade, additionally, more and more attention has been paid to the disciplinary effects of developing human rights indicators, measuring, and monitoring them. ${ }^{28}$ In all cases, it is clear that the more human rights treaties are in line with 
domestic concerns and processes, the higher the chances of having an impact.

This all, of course, concerns the national level. In attempting to better understand how treaty obligations impact individual lives, and how these processes of localization take place, one must adopt a user's perspective and investigate the processes by which specific rights travel to, and are mobilized by, a given setting. ${ }^{29}$ Such a setting, often referred to as a "semi-autonomous social field," can be a school, a health care institution, a village, or a particular community in which individuals and key stakeholders might mobilize human rights law to further specific social goals, align such law with existing cultures and beliefs, or opt to let other norms prevail. ${ }^{30}$ Mobilizing human rights in a particular local context is a patchy process in which actors and the information they have play a key role. Sally Engle Merry has labelled the process by which universal norms are translated to be in line with local cultural beliefs, religion, and traditions that of 'vernacularization', and has pointed at the key role of 'translators' in these processes. ${ }^{31}$ In all, it is clear that "universal principles, when applied to particular contexts, inevitably take on different forms. This happens within manifold constellations of power," in which global, national, and local contexts are mutually constitutive and norms are negotiated cross-culturally. ${ }^{32}$

Even if the combined insights from political science, sociology, and anthropology have substantially heightened our insight into the processes of treaty enforcement, these insights are often general, and pay little attention to, for example, the degree to which some treaty provisions are mobilized where others remain dormant. Similarly, little attention is paid to the temporal dimension of treaty implementation: how a treaty provision largely ignored at one point in time, can be mobilized and acquire meaning in another political dispensation.

One particularly surprising lacuna in the social science literature on treaty implementation concerns the period between signing and ratifying human rights treaties. ${ }^{33}$ Most literature either focuses on the international negotiations pertaining to a treaty or takes the moment of ratification as a point of departure. Ratification, here, is an international act, conducted at the international plane, as is signing a treaty. ${ }^{34}$ In the most important scholarship on the relationship between the international and domestic processes of treaty negotiation, Robert Putnam conceives of these processes as a "two-level game" in which negotiators must simultaneously ensure that an identical agreement is supported on both sides, which can have very different interests. ${ }^{35}$ More recently, a number of scholars have criticized this work for failing to take into account the sequential character of these processes. ${ }^{36}$ Jeffery Lantis, for instance, sets out the conditions for ratification in the "post-commitment phase," like the executive strategies involved, the type of electoral system, interest group pressure, and public support. ${ }^{37}$ Carlos Costa adds the importance of transnational processes, with actors studying and anticipating what key actors in other countries do. ${ }^{38}$ Even if such scholarship signals a marked lack of attention for the ratification phase; the way in which domestic treaty interpretation, and thus implementation, is foreshadowed by the legislative process hardly receives any attention.

Thus, the period of ratification is the time in which the treaty is introduced into the domestic arena and in which (successive) governments and political parties take a position on different treaty provisions. In addition, parliaments have their say on how they would like to see a treaty implemented and substantial lobbying pertaining to a treaty takes place. Of course, marked differences exist between monist systems (in which international law is considered to be a part of national law) and dualist systems (in which international law requires translation into national law) in the legislative enactment of a treaty. ${ }^{39}$ Nevertheless, the political processes often do not differ significantly because, often, treaties will require amendments to be made to existing legislation or introduction of new legislation in either type of government system. ${ }^{40}$ The 
literature that exists on the period between signing and ratifying treaties focuses largely on the legal obligations in the preratification period, as set out in Article 18 of the Vienna Convention, setting out how countries, once they have signed, cannot defeat the object and the purpose of a treaty. ${ }^{41}$ The importance of a focus on preratification politics, in contrast, is illustrated by the amount of time that it takes countries worldwide to ratify a treaty. For countries that end up ratifying a treaty, this process takes three years and ten months on average.

\begin{tabular}{|c|c|c|c|c|c|c|}
\hline $\begin{array}{l}\text { Treaty } \\
\text { (ratified) }\end{array}$ & $\begin{array}{l}\text { Europe } \\
\text { Central Asia }\end{array}$ & Africa & Americas & $\begin{array}{l}\text { Asia } \\
\text { Pacific }\end{array}$ & $\begin{array}{l}\text { Middle } \\
\text { East } \\
\text { N.Africa }\end{array}$ & World \\
\hline CAT (62) & 3 years & $\begin{array}{l}5 \text { years, } 10 \\
\text { m. }\end{array}$ & $\begin{array}{l}3 \text { years, } 8 \\
\mathrm{~m} .\end{array}$ & $\begin{array}{l}4 \text { years, } 4 \\
\text { m. }\end{array}$ & 4 years, $3 \mathrm{~m}$. & 3 years, $6 \mathrm{~m}$. \\
\hline CCPR (59) & 5 years, $8 \mathrm{~m}$. & 8 years & $\begin{array}{l}7 \text { years, } 10 \\
\mathrm{~m} .\end{array}$ & $\begin{array}{l}7 \text { years, } 8 \\
\mathrm{~m} .\end{array}$ & 9 years, $6 \mathrm{~m}$. & 7 years, $2 \mathrm{~m}$. \\
\hline CED (36) & 4 years & 2 years, $9 \mathrm{~m}$. & $\begin{array}{l}2 \text { years, } 5 \\
\mathrm{~m} .\end{array}$ & 5 years & 3 years, $8 \mathrm{~m}$. & 3 years, $7 \mathrm{~m}$. \\
\hline $\begin{array}{l}\text { CEDAW } \\
\text { (72) }\end{array}$ & 4 years, $3 \mathrm{~m}$. & 6 years, $1 \mathrm{~m}$. & $\begin{array}{l}2 \text { years, } 7 \\
\mathrm{~m} .\end{array}$ & $\begin{array}{l}2 \text { years, } 7 \\
\text { m. }\end{array}$ & $\begin{array}{l}5 \text { years, } 10 \\
\text { m. }\end{array}$ & 3 years, $6 \mathrm{~m}$. \\
\hline CERD (65) & 4 years, $3 \mathrm{~m}$. & 6 years, $1 \mathrm{~m}$. & $\begin{array}{l}6 \text { years, } 11 \\
\mathrm{~m} .\end{array}$ & 5 years & $\begin{array}{l}5 \text { years, } 11 \\
\text { m. }\end{array}$ & 6 years, $11 \mathrm{~m}$. \\
\hline $\begin{array}{l}\text { CESCR } \\
\text { (59) }\end{array}$ & 6 years, $5 \mathrm{~m}$. & $\begin{array}{l}11 \text { years, } 1 \\
\text { m. }\end{array}$ & $\begin{array}{l}6 \text { years, } 8 \\
\mathrm{~m} .\end{array}$ & $\begin{array}{l}6 \text { years } \\
\text { and } 1 \mathrm{~m} .\end{array}$ & 9 years, $6 \mathrm{~m}$. & 7 years \\
\hline CMW (20) & 2 years, $5 \mathrm{~m}$. & 2 years, $4 \mathrm{~m}$. & $\begin{array}{l}4 \text { years, } 6 \\
\mathrm{~m} .\end{array}$ & $\begin{array}{l}7 \text { years, } 8 \\
\text { m. }\end{array}$ & 2 years & 3 years, $10 \mathrm{~m}$. \\
\hline CRC (102) & 1 year, $11 \mathrm{~m}$. & 0 year, $9 \mathrm{~m}$. & $\begin{array}{l}1 \text { year, } 2 \\
\mathrm{~m} .\end{array}$ & $\begin{array}{l}1 \text { year, } 2 \\
\mathrm{~m} .\end{array}$ & 1 year, $9 \mathrm{~m}$. & 1 year, $6 \mathrm{~m}$. \\
\hline $\begin{array}{l}\text { CRPD } \\
\text { (102) }\end{array}$ & 2 years, $10 \mathrm{~m}$. & 3 years & $\begin{array}{l}2 \text { years, } 4 \\
\mathrm{~m} .\end{array}$ & $\begin{array}{l}2 \text { years, } 7 \\
\mathrm{~m} .\end{array}$ & 2 years & 2 years, $7 \mathrm{~m}$. \\
\hline $\begin{array}{l}\text { All UN } \\
\text { Human } \\
\text { rights } \\
\text { Treaties }\end{array}$ & 3 years, $10 \mathrm{~m}$. & 4 years, $9 \mathrm{~m}$ & $\begin{array}{l}3 \text { years, } \\
9 \mathrm{~m}\end{array}$ & $\begin{array}{c}3 \text { years, } \\
9 \mathrm{~m}\end{array}$ & 4 years, $8 \mathrm{~m}$ & 3 years, $10 \mathrm{~m}$. \\
\hline
\end{tabular}

The purpose of this article is to develop a theory on the politics involved in the preratification phase of human rights treaties grounded in one particular case study: the ratification of the CRPD in the Netherlands. The Netherlands forms a particularly interesting country in this regard. It is a monist country, in which international human rights treaties, once ratified by means of publication in the Government Gazette, automatically become part of Dutch 
law and can grant subjective rights to individuals in the Netherlands. ${ }^{42}$ Given the consequences, treaty ratification generally takes a long time in the Netherlands - six years on average for all treaties other than the CRPD in contrast to the global average of three years and ten months. The country also often prides itself upon first ensuring full treaty compliance before ratification takes place. ${ }^{43}$ With the CRPD, the Netherlands took nine years and three months before ratification, as opposed to a global average of two years and seven months. ${ }^{44}$ In this period, the Netherlands had three different coalition governments: one under the leadership of the Christian Democrat JanPeter Balkenende and two under the leadership of the Liberal Democrat Mark Rutte. Just as the Netherlands is an interesting case study to serve as a basis for formulation of theories on preratification politics, so is the CRPD a relevant treaty to consider. As with other specialist treaties, it might seek to bring about a paradigm change, but does not necessarily involve the introduction of new rights. ${ }^{45}$ The drawing up of a specialist treaty is thus about the politics of mobilization - internationally, nationally, and locally - and about explaining that human rights also apply to a particular vulnerable group — be it women (CEDAW), children (CRC), or migrant workers (CMW). With this in mind, let us turn towards an introduction of the CRPD and the particulars of its implementation in the Netherlands.

\section{The Disability Convention and the Dutch}

The United Nations Adopted the Convention on the Rights of Persons with Disabilities on 13 December 2006, together with its Optional Protocol, reportedly after the swiftest negotiations ever. ${ }^{46}$ It is heralded for strengthening the plight of the world's largest minority, an oftendiscriminated group, and for bringing "those in darkness into light." 47 Upon the adoption of the Convention, the UN High Commissioner on Human Rights noted how the adoption "enshrines a 'paradigm shift' in attitudes that moves from a view of persons with disabilities as objects of charity, medical treatment and social protection to subjects of rights, able to claim those rights as active members of society." 48 This rights-based understanding, which sees people living with disabilities as citizens, is apparent in the guiding principles of the Convention: autonomy, nondiscrimination, inclusion, respect for difference, equality of opportunity, accessibility, equality of men and women, and respect for the evolving capacities of children with disabilities. The Convention covers a very wide array of civil, political, social, economic, and cultural rights, thus reiterating most of the rights included in the UN Bill of Rights and stipulating their applicability to people living with disabilities.

One striking aspect of the CRPD was thus the-relative-speed of the negotiations involved and of the adoption of the treaty. A Committee of Experts on the Disabled might have recommended an international Convention in 1987, but the formal negotiations only startedupon the initiative of Mexico - in 2001, making it only five years for the formulation and adopted of the Convention. One special element in the negotiations was the strong participation of people with disabilities and their representative organizations in the process. The Ad Hoc Committee on a Comprehensive and Integral International Convention to Promote and Protect the Rights and Dignity of Persons with Disabilities, established in 2001, contained 40 country representatives and 400 representatives of NGOs and DPOs. ${ }^{49}$ For the first time, not only were ECOSOC-accredited groups allowed to participate, but also those without such accreditation, making for "totally unprecedented" participation. ${ }^{50}$

It is not only the degree of NGO-participation that illustrates the extent to which the CRPD is truly the first twenty-first century human rights treaty. The Disability Convention is distinctly modern because of how it incorporates recent insights on both the causes of human 
rights violations and ways of combating them. . It recognizes, for instance, the degree to which a disability is a social construction, stating in the preamble that "disability is an evolving concept and that disability results from the interaction between persons with impairments and attitudinal and environmental barriers that hinders their full and effective participation in society on an equal basis with others." 51 Lisa Waddington comments how the CRPD, in reflecting "the reality that disability stems primarily from the failure of the social environment to meet the needs and aspirations of people with impairments . . . is the highest legal manifestation and confirmation of the social model of disability on the international stage." 52 It also focuses on the intersectionality of rights violations, with specific provisions setting out the rights of women and children, specifying, for instance, that "women and girls with disabilities are subject to multiple discrimination" and stipulating the need to take into account the "best interests" of the child in all actions involving children with disabilities. ${ }^{53}$

Where it concerns specific provisions to ensure optimal implementation of the Convention, the CRPD gives explicit attention to actors other than the nation state. As said, this is the first UN Convention ratified by the European Union, which was closely involved in the negotiation of the Convention. ${ }^{54}$ The CRPD also brings innovation in the field of monitoringthat has surged to the fore in human rights interpretation discussions: it sets up its own monitoring body, the Committee on the Rights of Persons with Disabilities, but also explicitly regulates the relationship with the specialized agencies and other UN organs, calling for consistency in their suggestions, guidelines, and recommendations. It also contains the "most complete provision on national level implementation and monitoring ever in an international human rights treaty." 55 This is because it calls for the appointment of a national monitoring body, including the option of a coordination point and subnational monitoring bodies and because it calls for the establishment or strengthening of monitoring mechanisms..

The Dutch government, by its own admission, was initially not in favor of a specialist treaty, and thus another human rights Convention - it felt that persons with disabilities already had enough protection under the existing UN Treaties. ${ }^{5657}$ It was only when it became clear that adoption of the Convention was inevitable that the Netherlands actively joined the negotiation process, trying to ensure that the treaty would not contain any new rights. Once the Convention was adopted, the Netherlands was amongst the first of eighty-one countries to sign it on the 30 March 2007, be it with six interpretative declarations. ${ }^{58}$ It is striking that the press attention to the signature, and the parliamentary discussions at the time, focused largely on the foreign policy implications of the Convention. ${ }^{59}$ This is in line with a wider Dutch tendency towards "human rights exportism": considering human rights to-above all-be a foreign policy objective, which is only slowly starting to change. ${ }^{60}$ In spite of the rapid signature, the Minister of Foreign Affairs warned the Parliament in 2008 that it could take a long time for the Netherlands to ratify the Convention, as research concerning implementing legislation would have to take place first. ${ }^{61}$ The cabinet at the time (consisting of the Christian Democrats (CDA), the Christian Union (CU) and the Social Democrats (PvdA)) that sat until 2010 did not undertake any action towards ratification, nor did the cabinet that followed (consisting of the Liberal Democrats (VVD) and the CDA) that only sat for two years, until 2012. ${ }^{62}$

In 2012, five years after the Netherlands had signed the CRPD, the Governmental Agreement included the resolve to ratify the treaty, but with the ominous condition that "the duties related to it would be implemented gradually." 63 The only action before the time had been a parliamentary motion calling on the government to ratify and the commissioning of reports on the financial and legal consequences of ratification. ${ }^{64}$ A 2011 civil society position paper states 
that the Dutch reticence towards ratification was due to a combination of a fear of loss of sovereignty, opposition by employers, silence on the side of the unions, and general opposition within the biggest party, the VVD. ${ }^{65}$ In all, it was not until 2015 that the government put a bill concerning ratification to Parliament. The House of Representatives discussed this bill in December 2015 and January 2016, and agreed upon by the Senate in April, after which formal ratification took place in July 2016. It is possible that the process would have taken much longer without the persistent pressure from civil society and from "above" and "below." Civil society, for instance, was united in the Coalition for Inclusion that, for the first time in history, brought together a wide variety of organizations that organized conferences on "Making the UN Treaty Happen" (VN Verdrag waarmaken) and set up a website and a social media campaign on the topic, and was part of the wider umbrella organization "All(in)" (Ieder(in)). Part of the pressure on the Dutch government also came from the European Union that had already ratified the Convention in 2010. ${ }^{66}$ Additionally, a number of Dutch municipalities symbolically ratified the Convention and began to implement it, thus exerting bottom-up pressure on the process. ${ }^{67}$

\section{A Typology of Preratification Politics}

In their seminal work, Closing the Rights Gap: From Human Rights to Social Transformation, LaDawn Haglund and Robin Stryker set out not only the mechanisms, but also the actors and pathways that interplay in realizing social transformation by means of human rights. The preratification period, as such, could be considered a mechanism of implementation in itself, geared towards renegotiating the implications of the treaty in the domestic context. This important phase sets the stage for the impact that a treaty may have, far away from the international arena and firmly planted into the domestic context, with all the interests at play.

Even if the formal steps in this preratification period depend on the national context, the Dutch case can serve as an example of how the formal moments in the legislative process also enable political influencing. ${ }^{68}$ These steps include the following: the government, in the case of a treaty, prepares a bill containing the initiative to ratify the treaty. Before this, it consults with citizens and other organizations, and can ask for external advice. In the case of the CRPD, for example, the Ministry of Social Affairs and Employment asked first the Human Rights Research Centre SIM and then the Rotterdam School of Economics to prepare a report on the legal and financial consequences of ratification in 2012 and 2013. ${ }^{69}$ Subsequently, the government asks the Advisory Division of the Council of State for its advice. It is only then that the Bill proposing ratification, with an extensive Memorandum of Explanation, is given to the House of Representatives. It can be accompanied with proposals to adopt existing legislation, as was the case here with the Electoral Code and the Equal Treatment Act pertaining to Disabilities and Chronic Illnesses. ${ }^{70}$ The responsible parliamentary committee first discusses the Bill, after which the government prepares a further Explanatory Memorandum. It is only then that it is tabled for a plenary session in Parliament, in this case in late 2015, early 2016. During the plenary discussion, the House of Representatives - which has the right of amendment - can call attention to certain features, or put certain demands to government, via parliamentary motions. Once Parliament has adopted the Bill, it goes to the Senate, which formally has more of a revising role and cannot ask for amendments, even if it can table motions. If the Senate adopts a Bill, as was the case with the CRPD, it acquires the force of law upon publication in the Government Gazette. In the case of the CRPD this took place on the 14 April 2016. ${ }^{71}$ Formal ratification, as an international act, took place on the 14 June 2016, after which implementation still had to start.

Within this whole process, stakeholders can interpret treaty provisions at many different 
moments. This is important, as one consequence of the multilateral UN negotiations is that the provisions are generally very vague and open to multiple interpretations. ${ }^{72}$ The stakeholders include, first of all, the government itself. In addition, with an all-encompassing treaty like the CRPD, stakeholders included employers, businesses, the education sector, the transport and hospitality sector, insurance companies, and a wide variety of non-governmental organizations. These stakeholders are not a homogeneous block. Within government, for instance, the Ministry of Foreign Affairs would, behind the screens, emphasize the advantages of treaty ratification for the international position of the Netherlands, whereas the Ministry of Economic Affairs, or Social Affairs and Employability had concerns about the financial consequences of treaty ratification. In addition, there are political and even personal divides that determine governmental and parliamentary positions - in this process, for instance, the PvdA very much took the lead whereas the VVD showed much more reticence. A PvdA parliamentarian in a wheelchair, Otwin van Dijk, was recognized by many as the driving force behind treaty ratification, and recounted during the parliamentary debate how, when he first entered Parliament, the doors were still too heavy to be opened by someone in a wheelchair. ${ }^{73}$

A key driving force behind the legislative process, however, was civil society, which also consisted of a myriad of interests, ranging from the Deaf Society to the Foundation for Hyperventilation and the Association on Automutilation. Many of these civil society organizations started cooperating for the first time as a result of the impending treaty ratification and went through the process of reframing their particular concern as a human rights concern, in which the cooperation between organizations strengthened the effectiveness of their lobby. This lobby took place via background reports, thematic meetings, letters to, and discussions with, individual parliamentarians, and a clear presence at marking moments in the legislative process, as well as via the general media and a very active social media campaign. The hashtag \#VNVerdrag (\#UNTreaty) was combined with other tags to add particular emphasis, for instance \#hulphonden (\#assistancedogs), \#pleeback (\#toiletback) on toilets in trains, and \#jekomternietin (\#Youcantgetin), \#wijstaanop (\#Westandup), and \#toegankelijkheid (\#Accessibility) to emphasize the importance of accessibility in general.

In analyzing the processes of interpretation and renegotiation that took place in the CRPD preratification phase, one can distinguish three distinct strategies followed by key stakeholders: highlighting, downplaying, or simply ignoring treaty obligations. Highlighting took place where the government, for instance via extensive attention in the Explanatory Memorandum, brought specific treaty obligations to the fore or when it was forced to do so at a later stage via parliamentary motions backed up by media pressure. On the other hand, the government also engaged in downplaying certain requirements via what one could call a preemptive minimization of treaty obligations. Treaty obligations were also simply be ignored in the sense that they were not explicitly elaborated upon by the government or picked up by parliamentarians and interested organizations. The following sections will provide a brief example of each process.

\section{A. $\quad$ Highlighting Treaty Obligations: The Example of Accessibility}

In the CRPD preratification period, by far the largest share of governmental, parliamentary, and public attention went to the issue of accessibility. Article 9(1) of the CRPD holds that:

To enable persons with disabilities to live independently and participate fully in all aspects of life, States Parties shall take appropriate measures to ensure to persons with disabilities access, on an equal basis with others, to the physical 
environment, to transportation, to information and communications, including information and communications technologies and systems, and to other facilities and services open or provided to the public, both in urban and in rural areas. These measures, which shall include the identification and elimination of obstacles and barriers to accessibility, shall apply to, inter alia:

(a) Buildings, roads, transportation and other indoor and outdoor facilities, including schools, housing, medical facilities and workplaces;

(b) Information, communications and other services, including electronic services and emergency services. ${ }^{74}$

The extent of State Party obligations was further set out in the General Comment No. 2 of the CRPD Committee, which set out the precise state obligations in terms of the physical environment, transportation, information, communication, and services, stipulating how publically accessible buildings, no matter their ownership, should be accessible to all. It emphasized the duty to apply universal design to all new goods, products, facilities, technologies, and services. States parties, additionally, are required to take measures to ensure that private entities that offer facilities and services to the public consider all aspects of accessibility for persons with disabilities. ${ }^{75}$ The Committee also stipulated that the duty to implement accessibility is unconditional. The General Comment stipulated state obligations, such as gradually and systematically removing barriers and adopting, promulgating, and monitoring standards.

The Dutch government, in its explanatory memorandum, already paid a great deal of attention to the general importance of accessibility. In particular the government stressed access to public spaces and to information, with a detailed overview of current practice and actions to take in the near future, often with direct reference to EU legislation. ${ }^{76}$ This focus was increased by an emphasis on the issue by NGOs consulted during the process and intensive social media activity under hashtags as \#Jekomterniet in (\#Youcantgetin) or \#toegankelijkheid (\#accessibility), pointing out striking examples of buildings, parks, trains, and libraries inaccessible to people with disabilities. The parliamentarian who was the driving force behind treaty ratification, Otwin van Dijk, indicated repeatedly how making accessibility the norm was the reason he entered Parliament. As a result, the importance of accessibility was highlighted in a number of motions and proposed amendments to legislation adopted in Parliament, on topics like a monitoring the role of the National Human Rights Institute on this topic, accessibility of buildings, accessibility of digital governmental information, and the removal of barriers for political participation (for instance in voting boots). Even if these are state obligations included in the CRPD, the motions served to highlight the importance of these aspects of accessibility for a parliamentary majority. ${ }^{77}$

To a large extent, the government's resistance to make accessibility a general principle triggered attention to this topic in parliamentary discussions. The State Secretary, clearly under the influence of the VVD party, took the position that the CRPD did not have any consequences for private parties. The law to give effect to the Convention (uitvoeringswet) would include an amendment to the Law on Equal Treatment on the Basis of Handicap or Chronic Disease (WGBH/CZ) concerning goods and services that would oblige parties to provide reasonable accommodation, not imposing a disproportionate burden, without reference to the other obligations set out in Article 9 of CRPD. The government's examples included (1) someone who cannot walk well but has to climb two stairs to enter a hairdresser, can ask the hairdresser for 
help, or for a plank to be put down; and (2) a person with a visual impairment can ask restaurant personnel to read out the menu. ${ }^{78}$ Parliamentarians felt that this did not go far enough in establishing a general norm: "Why would someone who is disabled have to beg for accommodation in a restaurant, public transport or a shop?."79 They proposed an amendment stating that all parties addressed by this particular anti-discrimination law needed to take due care of general accessibility, unless this would be an unreasonable burden.

This proposal nearly caused the Liberal Democrats to withdraw support for the CRPD. They only reluctantly agreed after a provision was included stating that the actual obligations of the provision would be worked out in a governmental decree $(a m v b)$. The concept-decree, published in October 2016, reopened the discussion by stating that the obligations in the provision only concerned "simple adaptions" (voorzieningen van eenvoudige aard). It also stated that - in deciding what constituted an unreasonable burden - attention would be giventhe size of the organizations, the costs, the use, the life of the infrastructure concerned, the historic/cultural/architectural value of the object, and the safety and feasibility of the measures to be taken. ${ }^{80}$ The concept-decree included some examples of simple adaptations ("that can be brought about with little to no costs and effort") like removing objects restraining wheelchairs in a shop, putting down background music when so requested by people with a hearing impairment, and "paying enough time and attention to people with a mental disability, for instance in explaining a good or a service." 81 The facts that the decree did not include a definition of accessibility, a timeframe, nor refer to the general norm or the CRPD, lead to furious civil society responses and tweets stating-in Dutch - that \#Youcantgetin would now become \#Youwillnevergetin. ${ }^{82}$

Even though the issue of accessibility came to dominate the parliamentary proceedings, this does not mean the government intended to completely follow the CRPD in this regard. As the State Secretary wrote in response to a parliamentarian who asked whether the government intended to implement the treaty by the letter: "The treaty does not have direct effect. Implementing legislation ensures a translation towards the Dutch situation." 83 The final decree, passed in June 2017, did include a strong position of civil society and attention for the process of implementation, but still contained the watered-down provisions on 'simple adaptations' and the broad provisions allowing organizations to invoke 'unreasonable burden' as a reason to not implement measures. ${ }^{84}$ As is often the case in giving meaning to human rights treaties, the extent of the rights foreseen by the treaty actually granted in a given context only becomes apparent in the small print of administrative law. The discussion on accessibility does show, however, how some issues can become subject to vehement national renegotiation, finding their (watered down) way into national laws and policies, whereas others, as we will see, do not receive any attention.

\section{B. Downplaying Obligations: The Issue of Justiciability}

In the Netherlands, the CRPD's consequences on accessibility were a main topic of debate from the very start-be it with notable differences in the interpretation. One might call the next strategy, mostly in the hands of the government, 'preemptive minimization.' or the simple downplaying of treaty obligations. Here, the justiciability of treaty provisions is a case in point. One important question pertaining to the CRPD is the degree to which the rights it contains allow individuals to claim them before a court. The fact that the CRPD comes with an Optional Protocol that allows individuals to complain about infringements of the Convention is, in itself, an indication of the fact that the document does, in part, contain such subjective rights. The 
possibility of individual complaints does not only concern civil and political rights, but also the economic, social, and cultural rights listed in the Convention to the extent that they allow such interpretation. ${ }^{85}$ As an example, the CRPD committee, in the case of Bujdosó v. Hungary stated that individual plaintiffs, with mental disabilities, had the right to vote. ${ }^{86}$

Taking a very narrow understanding of the future justiciability of the Convention, the government, in its explanatory memorandum emphasized that the whole issue of justiciability had not been explicitly discussed during the treaty negotiations. In what seemed like a dialogue agreed upon beforehandbetween the Liberal Democrats in Parliament (who asked, "can the government confirm that the CRPD does not contain provisions with direct effect?") and the government, the latter indicated that only the provisions that had been given direct effect elsewhere would have justiciability in the Convention. ${ }^{87}$ This highly restrictive interpretation of treaty obligations was aided by the ruling of the European Court of Justice, which has been criticized by legal scholars, who wrote that "[w]hile the case has been noted for drawing a distinction between rights and principles ... the most significant contribution it makes is in demoting both." 88 It is in line, however, with earlier Dutch governmental hesitance to recognize the justiciability of socio-economic rights. ${ }^{89}$ It is in this light, also, one should consider the fact that Netherlands has not signed the Optional Protocol to the CRPD.

The ratification of the Optional Protocol was - unlike accessibility - not a civil society or media concern, possibly because the issue was too technical. The issue was subject to some parliamentary debate, with parliamentarians wondering what held the government from ratifying given the fact that nearly ninety countries, including neighboring Belgium, Germany, and the UK had already done so. The formal governmental position was that ratification must be considered in relation to ratification of the protocols to the ICESCR and the CRC, both of which the Netherlands has signed but not ratified. ${ }^{90}$ In the debate in the Senate, the State Secretary indicated that it would be necessary to investigate "what this would add to the Dutch possibilities, what it means for administrative burden and for existing legislation." $91 \mathrm{He}$ explained that there are treaties for which there is already enough recourse in Dutch law, and that the government - in these cases - does not what to create "an alternative form of legal recourse without understanding how this would have effect on our own system." 92 One senator pointed out that this seemed like "an old-fashioned game of playing for time," an assessment that seemed confirmed when the government stated in June 2016 that it would get back on the issue of ratification of the Optional Protocol, indicating that the "necessary discussions had not yet been finalized," and repeating that message in September. ${ }^{93}$

Whereas it is much too early to assess whether Dutch judges, who have the last word in this matter, will allow individual persons with disabilities to call on the Convention in a concrete case, the legislative process set the stage for a very restrictive interpretation and, ultimately, less protection of the people concerned. It could well be that the relatively technical matter of the legal implications of ratifying the Optional Protocol for subjective rights explains why civil society was much more silent on this issue than on others, thus enabling the government to set the stage for an interpretation that differs markedly from the international standard. The NGO 'In1school', that has announced strategic litigation in order to realize inclusive education, will thus find its case potentially hampered by this legislative history. ${ }^{94}$

\section{Ignoring Obligations: The Example of Inclusive Education}

The issue of justiciability was subject to extensive discussions, within Parliament and in the reports of the Council of the State and human rights research groups. Here, there is a marked 
contrast with an issue that could very well have been on the table, but was not: inclusive education. Article 24(2) of the Convention explicitly enshrines the right to inclusive education, stating that State Parties shall ensure that:

(a) Persons with disabilities are not excluded from the general education system on the basis of disability, and that children with disabilities are not excluded from free and compulsory primary education, or from secondary education, on the basis of disability;

(b) Persons with disabilities can access an inclusive, quality and free primary education and secondary education on an equal basis with others in the communities in which they live. ${ }^{95}$

There is a clear contrast here with the Dutch system of segregated education, in which 5 percent of the Dutch pupils attend special needs schools. ${ }^{96}$ The government, however, in the Explanatory Memorandum to the CRPD redefined inclusive as meaning "that nobody is excluded from education," to continue to describe the Dutch system of regular schools and special schools for children living with disabilities. ${ }^{97}$ In 2009, for instance, the government informed Parliament that special education would continue to exist, with the State Secretary quoted as saying: "we've tried inclusive education and it was failure, so we will not discuss that again." 98

Even more striking is the fact that the Netherlands, eight years after signing the CRPD, adopted a new law - the Law on Fitting Education (Wet Passend Onderwijs) - in 2014 that explicitly kept the old system in place. ${ }^{99}$ The purpose of the Law on Fitting Education was to enable more students in special education to go to regular schools. At the same time, these schools did not receive extra resources, something that many criticized. In spite of the direct relationship with Article 24(2), the Memorandum introducing the Law on Fitting Education in 2014 did not refer to the CRPD once. ${ }^{100}$

The theme of inclusive education was only raised in the written rounds preceding parliamentary discussion of the CRPD. Here, parliamentarians asked the government why it had not paid attention to inclusive education in the legislative proposals concerning the CRPD, especially in light of the CRC and the Salamanca Declaration. ${ }^{101}$ The government pointed at the Dutch tradition of separate regular and special education, also in the light of Dutch geography: "In a densely populated country like the Netherlands both regular and special education are within a reasonable distance. This makes is less necessary to, because of travel time, realize special education." "102 It also pointed at Fitting Education's goal to support special needs students in attending regular education-wherever possible. The issue of inclusive education, conversely, was not discussed again in the plenary discussions on the CRPD in Parliament and in the Senate. ${ }^{103}$ Even where newspapers and parents reported concerns about the effects of the new legislation on access to education for children with disabilities, these were not framed in terms of the CRPD objectives.

Explanations of this relative neglect of Article 24(2) of the CRPD also must include the fact that experts and expert organizations often did not know the CRPD or did not support the objective of inclusive education. When the directors of a consortia of regular and special schools on implementing Fitting Education (samenwerkingsverbanden) were asked about the normative basis for extra support 98 percent pointed at the children's need for support, whereas only 1 percent pointed at the principle of inclusive education. ${ }^{104}$ Out of the 59 specialist legal articles on the new Law on Fitting Education that appeared after 2009, for instance, none refers to the CRPD. ${ }^{105}$ NGOs, with the exception of the Alliance of Organizations of People with a Disability, did not raise the point or push it later on in the process. The ignoring of treaty obligations here, it 
seems, took place upon the initiative of government but was strengthened by a lack of parliamentary, civil society, and expert endorsement of the issue at hand.

The Law on Fitting Education is an example, but was only one out of a large package of measures taken by the post-2010 government that affected people living with disabilities. In this period, the government implemented a large-scale decentralization operation, in combination with severe budget cuts. The new Law on Social Support (Wet Maatschappelijke Ondersteuning (WMO)), adopted in summer 2015, for example, not only made municipalities responsible for social support to the disabled, but also reduced their (individualized) budgets, making them more reliant on volunteer support. ${ }^{106}$ The Law on Participation (Participatiewet) made an end to social work facilities for the disabled, with the budget cuts concerned. The rationale was that this would stimulate people to take up regular jobs, and strengthen their participation in society. Both laws were severely criticized for their impact upon, amongst others, the disabled. These critiques, however, were not framed in terms of the CRPD obligations and the connection between these legislative proposals - passed after signing but before ratifying — and the CRPD was hardly ever made. It was only during the discussion on the CRPD in a right-wing politician scorned "[e]veryone understands that, if this treaty had been discussed first and the WMO and the other 105 budget cuts afterwards, there would not have been such a regression in services as is currently the case."107

\section{Conclusion}

During a parliamentary hearing on the CRPD a representative of the mental health care organizations said: "You really have to take care that this Convention does not become a fruit bowl out of which you pick those fruits you liked anyway." 108 Even if there is more socioscientific literature on the politics of implementation of human rights treaties, such literature often concerns treaties as a homogeneous whole and starts analysis of their impact after ratification. By taking a close look at the period between signature and ratification of the CRPD in the Netherlands, this article has focuses on preratification politics, setting out how these politics can ensure that one treaty provision becomes more important than another. In doing so, it shows how even in a country generally considered one of the most monist in the world the process of ratification can include substantial renegotiation of the normative content of treaties. The interplay between actors in government, Parliament, and society at large ensures that certain issues are highlighted, while others are downplayed or downright ignored. These perspectives, formally discussed in Parliament, become part of the legislative history of the treaty, and thus withing the Dutch legal system - influence the way it will be interpreted by judges. The issues discussed, in contrast to those ignored, become part of the collective consciousness of all stakeholders, thus ensuring that the parties involved in actually implementing a treaty will focus more on certain aspects than others. In the Netherlands, for instance, it is clear that the preratification process has put accessibility firmly on the policy agenda, whereas inclusive education is not closer (and possibly even further away) than it was when the Netherlands signed the CRPD. The governmental strategy of downplaying treaty obligations as a form of preemptive minimization is also notable. Whereas the actual impact of the CRPD in the Netherlands remains to be seen, one can see that a stage has been set in which some rights for the disabled are in much closer reach than others.

These findings shed light on processes of human rights implementation far beyond this particular country, or the case of the CRPD alone. Even if there are marked differences between the processes that accompany the ratification of human rights treaties worldwide, it is expected 
that similar politics are at play in other democracies. In other democracies, too, bills are accompanied by explanatory memoranda explanatory memorandum accompanies bills, in which the executive offers its understanding of the often wide-ranging treaty provisions and interprets them for domestic purposes. In other democracies, too, parliamentarians are often too busy, uninformed, uninterested, or preoccupied with other issues to take up the full range of issues addressed in a treaty, and thus inclined to focus on a number of points - be it presented to them as a result of political lobbying or by other means. Other democracies, too, will have some civil society organizations that are stronger and better equipped for advocacy than others, with each placing an emphasis on the issues that seem most attainable and in line with their direct interests. As such, the preratification phase is of crucial importance for the formal and informal interpretation and ultimately the implementation of treaties worldwide.

This has a number of consequences for the - rising - field of socio-scientific research on human rights implementation. If the ambition is truly to understand the effects of international human rights law in domestic settings one must consider, in terms of the timespan covered, looking at the preratification phase, instead of only starting research after formal ratification. Next, one should distinguish between the various treaty obligations to a much larger extent than is currently often the case. Finally, this case calls for comparative attention to the degree to which the domestic legal interpretation of treaty obligations, put forward as part of the ratification process, impacts the actual treaty. An old saying goes" "you never get a second chance to make a first impression". This also applies to human rights treaties: the way a treaty first enters the domestic scene is of more importance than has been recognized to date, most importantly for those rights holders who stand to benefit from it most. 
Endnotes

* Barbara Oomen is a Professor in the Sociology of Human Rights at Utrecht University, University College Roosevelt and a Fernand Braudel Fellow at the European University Institute for the 2016-2017 academic year. Her most recent book is Global Urban Justice: the Rise of Human Rights Cities. She currently leads the Cities of Refuge research project. This article was first presented at the Law \& Society Association 2016 conference and she is deeply indebted to all who commented. The research itself has been funded by the Interuniversity Attraction Poles Programme, initiated by the Belgian Science Policy Office, more specifically the IAP The Global Challenge of Human Rights Integration: Towards a Users' Perspective (www.hrintegration.be).

${ }^{1}$ Behandeling Verdrag inzake de Rechten van Personen met een Handicap (Parliamentary discussion on the Ratification of the Convention on the Rights of All Persons with Disabilities in the House of Representatives), law 33990 and 33992, Vergaderjaar 2015-2016,14 Jan. 2016, nr. 42 , item 9. All the legislative documents quoted in this article are retrievable at zoek.officielebekendmakingen.nl under the main files numbers 33990 (all documents pertaining to the Treaty) and 33992 (all documents pertaining to the Implementation Act). A useful overview of the legislative steps taken in this protracted process can also be found on the website of the Dutch Senate https://www.eerstekamer.nl/wetsvoorstel/33990_uitvoering_verdrag_inzake_de (last visited 14 February 2018).

${ }^{2}$ Compare Paul Harpur, Rights of Persons with Disabilities and Australian Anti-Discrimination Laws: What Happened to the Legal Protections for People Using Guide or Assistance Dogs, 29 U. TASMANIA L. REV. 49 (2010).

${ }^{3}$ See, for instance: Oona A. Hathaway, Do Human Rights Treaties Make a Difference?, 111 YAle L. J. 1935 (2002); RyAn GoOdMAN \& DereK Jinks, Socializing States: Promoting Human Rights Through International Law (2013).; Jasper Krommendijk, The Domestic Effectiveness of International Human Rights Monitoring in Established Democracies: The Case of the UN Human Rights Treaty Bodies, 10 REV. INT'L ORGS. 489 (2015); Gregory Shaffer \& Tom Ginsburg, The Empirical Turn in International Legal Scholarship, 106 AM. J. INT'L L. 1 (2012); Beth A. Simmons, MobiLIZING FOR Human Rights: INTERNATIONAL LAW IN DOMESTIC POLITICS (2009).

${ }^{4}$ One example is Simmons, whose highly influential book has a central thesis that "ratified treaties can influence agendas, litigation and mobilization in ways that should be observable in government policies post-ratification." SIMMONS, supra note 3, at 113. Exceptions to this general neglect of preratification politics are to be found in some recent political science literature on other types treaties like Leonardo Baccini \& Johannes Urpelainen, Before Ratification: 
Understanding the Timing of International Treaty Effects on Domestic Policies, 58 INT'L STUD. Q. 29 (2014); Yoram Z. Haftel \& Alexander Thompson, Delayed Ratification: The Domestic Fate of Bilateral Investment Treaties, 67 INT'L ORG. 355 (2013); Paul V. McDade, The Interim Obligation Between Signature and Ratification of a Treaty: Issues Raised by the Recent Actions of Signatories to the Law of the Sea Convention with Respect to the Mining of the Deep Seabed, 32 NETH. INT'L L. REV. 5 (1985).

5 The number three years and ten months is based upon an analysis of the UN OHCHR data on all UN human rights treaties ratified, including the CRPD, carried out in the week of 9 May 2016, with thanks to Laelia Dard Dascott. See also table 1 below.

${ }^{6}$ SimMONS, supra note 3 , at 5.

${ }^{7}$ Frédéric Mégret, The Disabilities Convention: Human Rights of Persons With Disabilities or Disability Rights?, 30 HuM. RTS Q. 494, 515 (2008).

${ }^{8}$ Convention on the Rights of Persons with Disabilities, adopted 13 Dec. 2006, G.A. Res. 61/106, U.N. GAOR, 61th Sess., art. 33, U.N. Doc. A/RES/61/106 (2006) (entered into force 3 May 2008).

${ }^{9}$ Kathy Charmaz, Constructing Grounded Theory: A Practical Guide Through QUALITATIVE ANALYSIS (2006).

${ }^{10}$ Shaffer \& Ginsburg, supra note 3 , at 1.

${ }^{11} I d$. at 6. For a rationalist approach see Andrew Moravcsik, The Origins of Human Rights Regimes: Democratic Delegation in Postwar Europe, 54 INT'L ORG. 217 (2000). For a constructivist approach see Gregory Shaffer \& Tom Ginsburg, The Empirical Turn in International Legal Scholarship, 106 AM. J. INT'L L. 1 (2012).

${ }^{12}$ GOODMAN \& JinKS, supra note 3, at 6.

${ }^{13}$ Raymond Lang et al., Implementing the United Nations Convention on the Rights of Persons With Disabilities: Principles, Implications, Practice and Limitations, 5 ALTER-EUR. J. DisABILITY RES. 206 (2011).

${ }^{14}$ SimMONS, supra note 3 , at 373.

15 The POWER OF HumAn Rights: InTERnATIONAL NORMS AND DOMESTIC CHANGE (Thomas Risse et al. eds.,1999). See also GoODMAN \& JINKS, supra note 3, at 148.

${ }^{16}$ Global Urban Justice: The Rise of Human Rights Cities (Barbara Oomen et al. eds., 2016).

${ }^{17}$ Neil Walker, The Idea of Constitutional Pluralism, 65 MoD. L. REV. 317 (2002);Armin von Bogdandy, Pluralism, Direct Effect, and the Ultimate Say: On the Relationship Between 
International and Domestic Constitutional Law, 6 INT’L J. ConsT. L. 397 (2008).

${ }^{18}$ Emilie M. Hafner-Burton \& Kiyoteru Tsutsui, Human Rights in a Globalizing World: The Paradox of Empty Promises, 110 AM. J. Soc. 1373, 1402 (2005).

${ }^{19}$ Clifford Bob, Globalization and the Social Construction of Human Rights Campaigns, in GLOBALIZATION AND HUMAN RIGHTS 133 (Alison Brysk ed., 2002).

${ }^{20}$ Michael Goodhart, Introduction: Human Rights in Politics and Practice, in HUMAN RIGHTS: POLITICS AND PRACTICE 1 (Michael Goodhart ed., 2009).

${ }^{21}$ At the same time, socio-legal scholars over the years have pointed out the limitations in litigation. Gerald N. Rosenberg, The Hollow Hope: Can Courts Bring About Social ChANGE? (2d ed. 2008).

${ }^{22}$ See Krommendijk, supra note 3, at 508.

${ }^{23}$ One example would be the influence of R. Lempkin on the Genocide Convention. THE ORIGINS OF GENOCIDE: RAPHAEL LEMKIN AS A HISTORIAN OF MASS VIOLENCE (Dominik J. Schaller \& Jürgen Zimmerer eds., 2009).

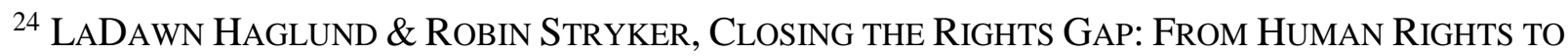
SOCIAL TRANSFORMATION 5 (2015).

${ }^{25}$ Christof Heyns \& Frans Viljoen, The Impact of the United Nations Human Rights TREATIES ON THE DOMESTIC LEVEL (2002). On the impact of treaty bodies' individual communications procedures see INTERNATIONAL LAW ASSOCIATION, FINAL REPORT OF THE IMPACT OF FINDINGS OF THE UNITED NATIONS HUMAN RIGHTS TREATY BODIES (2004); see also OPEN SOCIETY FOUNDATIONS, FROM JUDGMENT TO JUSTICE: IMPLEMENTING INTERNATIONAL AND Regional Human Rights Decisions (2010); Jasper Krommendijk, The Domestic Effectiveness of International Human Rights Monitoring in Establishing democracies. The Case of the UN Human Rights Treaty Bodies, 10 REV. INT'L ORG. 489 (2015).

${ }^{26}$ HAGLUND \& STRYKER, supra note 24, at 328; Krommendijk, supra note 25.

${ }^{27}$ HeYNS \& VILJOEN, supra note 25, at 35.

${ }^{28}$ See Todd Landman, Measuring Human Rights, in HUMAN RIGHTS: POLITICS AND PRACTICE, supra note 20 , at 46.

${ }^{29}$ Eva Brems \& Ellen Desmet, Studying Human Rights Law From the Perspective(s) of Its Users, 8 HuM. RTS \& INT'L LEGAL DisCOURSE 111 (2014); EIUC, THE LOCAL RELEVANCE OF Human Rights (Koen De Feyter et al. eds., 2011); Barbara Oomen \& Esther van den Berg, Human Rights Cities: Urban Actors as Pragmatic Idealistic Human Rights Users, 8 HuM. RTs \& INT'L LEGAL DISCOURSE 160 (2014). 
${ }^{30}$ The notion of a semiautonomous social field was first defined by Sally Falk Moore, Law and Social Change: The Semi-Autonomous Social Field as an Appropriate Subject of Study, 7 L. \& SOC'Y REV. 719 (1973), and plays a key role in literature on legal pluralism like Brian Z. Tamanaha, Understanding Legal Pluralism: Past to Present, Local to Global, 30 SYDNEY L. REV. 375 (2008).

${ }^{31}$ Sally Engle MerRy, Human Rights AND Gender Violence: Translating INTERNATIONAL LAW INTO LOCAL JUSTICE 210-12, 216 (2006).

32 Susanne Zwingel, How Do Norms Travel? Theorizing International Women's Rights in Transnational Perspective, 56 INT'L STUD. Q. 115, 126 (2012).

${ }^{33}$ See Haftel \& Thompson, supra note 4.

34 Anthony Aust, Modern Treaty LaW And Practice 95 (3rd ed., 2013).

${ }^{35}$ Robert D. Putnam, Diplomacy and Domestic Politics: The Logic of Two-Level Games, 42 INT'L ORG. 427, 434 (1988).

36 JEFFREY S. LANTIS, THE LIFE AND DEATH OF INTERNATIONAL TREATIES: DOUBLE-EDGED Diplomacy AND the Politics OF RATIFICATION IN COMPARATIVE PERSPECTIVE 4-5 (2009).

${ }^{37}$ Id. at 5-10.

${ }^{38}$ Carlos Closa, The Politics of Ratification of EU Treaties 180 (2013).

${ }^{39}$ Aust, supra note 34, at 163, 167.

${ }^{40}$ See Pierre-Hugues Verdier \& Mila Versteeg, International Law in National Legal Systems: An Empirical Investigation, 109 AM. J. INT'L L. 514, 515-16 (2015).

${ }^{41}$ Robert Kolb, The LaW of Treaties: An Introduction 43 (2016); McDade, supra note 4.

${ }^{42}$ This generally takes place via a "Goedkeuringswet," a law of agreement by which the treaty is ratified. See also Gw. [Dutch Constitution], art. 93; Joseph Fleuren, The Application of Public International Law by Dutch Courts, 57 NETH. INT'L L. REV. 245, 252-59 (2010).

${ }^{43}$ See, for instance, Senate Debate on the CRPD, law 33990, Vergaderjaar 2015-2016, 12 Apr. 2016, nr. 27. ) This debate can be viewed via https://www.eerstekamer.nl/verslagdeel/20160412/goedkeuring en uitvoering_verdrag. During the debate, the State Secretary Van Rijn stated how "Als wij iets ratificeren, willen wij heel goed kijken wat de consequenties zijn voor andere wetten. We hebben nogal wat wetten, dus het bekijken, doorvlooien, becommentariëren en bepalen welke wetten wel en niet aan het verdrag voldoen, is gewoon heel veel werk" (If we ratify something, we want to be very sure what the consequences are for other laws. We have quite a lot of laws, so considering, sifting through, commenting and deciding which laws do or do not comply with the treaty is simply a lot of work, translation author) 
${ }^{44}$ The Netherlands signed the CRPD on 30 March 2007. It was adopted by the Senate in January 2016 and is expected to be published in the government gazette, and thus ratified, in summer 2016 and was published in the Government Gazette, and thus ratified, in summer 2016.

${ }^{45}$ ARLENe S. Kanter, The DeVElopment of Disability Rights Under InTERnational LaW: From Charity to Human Rights 9 (2015); Mégret, supra note 7, at 494.

${ }^{46}$ Rosemary Kayess \& Phillip French, Out of Darkness into Light? Introducing the Convention on the Rights of Persons with Disabilities, 8 HuM. RTS. L. REV. 1, 1-2 (2008).

${ }^{47} I d$. at 3 .

${ }^{48}$ Statement by Louise Arbour, UN High Commissioner for Human Rights to the Resumed 8th Session of the Ad Hoc Commitee on the Convention on the Rights of Persons with Disabilities (5 Dec. 2006), available at http://www.un.org/esa/socdev/enable/rights/ahc8hrcmsg.htm. See also Danai Angeli, Positive Obligations in Human Rights Law: The Disabilities Paradigm Shift 19091 (20 Dec. 2015) (dissertation, European University Institute).

${ }^{49}$ Arlene S. Kanter, The Promise and Challenge of the United Nations Convention on the Rights of Persons with Disabilities, The, 34 SYRACUSE J. INT'L L. \& COM. 287 (2006). Tara J. Melish, The UN Disability Convention: Historic Process, Strong Prospects, and Why the U.S. Should Ratify, 14 HUM. RTS. BRIEF 37 (2007).

${ }^{50}$ Janet E. Lord, NGO Participation In Human Rights Law And Process: Latest Developments in the Effort to Develop an International Treaty on the Rights of People With Disabilities, 10 ILSA J. INT'L \& COMP. L. 311, 315 (2004).

${ }^{51}$ Convention on the Rights of Persons with Disabilities, adopted 13 Dec. 2006, G.A. Res. 61/106, U.N. GAOR, 61th Sess., pmbl, sub(e), U.N. Doc. A/RES/61/106 (2006) (entered into force 3 May 2008) [hereinafter CRPD].This was also reiterated by the EU Court of Justice: Case C-345/13, Fag og Arbejde v. Kommunernes Landsforening, ECLI:EU:C:2014:2463.

${ }^{52}$ Lisa Waddington, The European Union and the United Nations Convention on the Rights of Persons with Disabilities: A Story of Exclusive and Shared Competences, 18 MAASTRICHT J. EUR. \& COMP. L., 431, 436 (2011).

${ }^{53}$ CRPD, supra note 51, art. 6, 7. See Rosemary Kayess et al., International Power and Local Action -Implications for the Intersectionality of the Rights of Women with Disability, 73 AusT. J. PUB. ADMIN. 383 (2014).

${ }^{54}$ Waddington, supra note 52, at 432. 
${ }^{55}$ Gauthier de Beco, StUdy on the IMPLEMENTATION OF ARTICLE 33 OF THE UN CONVENTION ON THE RIGHTS OF PERSONS WITH DISABILITIES IN EUROPE 4 (2014); see CRPD, supra note 51, art. 32, 33; EILIONÓIR FLYNN, FROM RHETORIC TO ACTION: IMPLEMENTING THE UN CONVENTION ON THE RightS OF PERSONS WITH DisABILITIES 21 (2011).

${ }^{56}$ Concept by the Ministry, 2014, included in the official legislative history of the CRPD ratification in the Netherlands and retrievable via "ambtelijk concept 3392 2014" on the official government website, and on file with the author, p.3.

${ }^{57} I d$.

${ }^{58}$ Id.; CRPD, supra note 51, p.7. These declarations concerned, amongst others, Article 10, where the Kingdom states that unborn life is worthy of protection but that the effect of such protection, and the definition of "human being" is a matter for national legislation (with the farreaching Dutch abortion legislation in mind). With respect to art. 15 a declaration was made on the definition of consent, stating that for those who could not give consent it would be "permission given by their representative or an authority or body provided for by law. Concerning Article 23 the Netherlands declared that the best interests of the child would be paramount. With respect to Article 25 the Netherlands set out that 'good care involves respecting a person's wishes with regard to medical treatment, food and fluids."

${ }^{59}$ This statement is based on news items in all Dutch news sources retrieved via Lexis Nexis and the Memorie van Toelichting, Vergaderjaar 2013-2014, 33992 (R2034), nr. 3 (Explanatory Memorandum).

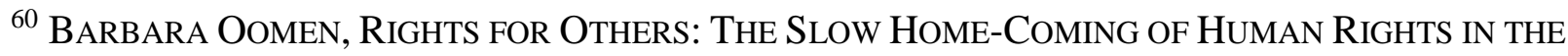
NETHERLANDS 4 (Chris Arup et al. eds., 2014).

${ }^{61}$ Mensenrechtenstrategie Voor het Buitenlands Beleid, Brief van de Minister Van Buitenlandese Zaken, Tweede Kamer, Vergaderjaar 2007-2008, 31 263, nr. 10 (Human Rights Strategy for Foreign Policy, Minister of Foreign Affairs). This is in contrast with promises of the Minister of Social Affairs at the time, who-also in 2008 - set out her intention to ratify the CRPD during the 2007-2011 government period (that actually ended in February 2010). See also L.Geldof van Doorn \& R. Oostland, Het Gehandicaptenverdrag: een Verdrag met Implicaties Voor Nederland (The CRPD: a treaty with implications for the Netherlands), NEDERLANDS JURISTENBLAD (2008). This and all translations below are an unofficial transaltions by the author.

${ }^{62}$ This Cabinet depended on the support of the Freedom Party (PVV) of Geert Wilders for its support, and was highly critical towards international treaties, calling - for instance- - for change of treaties where these hampered restrictive immigration policies. VRIJHEID EN VERANTWOORDELIJKHEID: REGEERAKKOORD, VVD-CDA (2010).

${ }^{63}$ BRUGGEN SLAAN: REGEERAKKOORD VVD - PVDA 18 (2012).

${ }^{64}$ Vaststelling van de Begrotingsstaten van het Ministerie van Volksgezondheid, Welzijn en 
Sport (XVI) Voor het jaar 2012, Motie van de Leden Leijten en Wiegman-van Meppelen Scheppink, Tweede Kamer, Vergaderjaar 2011-2012, 33000 XVI, nr. 43 (Setting of the budget of the Ministery of Health, Welfare and Sport).

${ }^{65}$ Coalitie voor Inclusie, Position Paper on the CRPD Ratification Process in the Netherlands: Unwilling or Just Really Slow? (25 Sept. 2012), available at http://www.vnverdragwaarmaken.nl/vnverdragwaarmaken/images/vnhome/Position_paper_to_M rsPillay_on_the_CRPD_in_the_Netherlands_sept_25_2012.pdf.

${ }^{66}$ See Waddington, supra note 52.

${ }^{67}$ Oomen \& van den Berg, supra note 29.

${ }^{68}$ Formally, this process is set out in Rijkswet Goedkeuring en Bekendmaking Verdragen (Law on the Ratification and Publication of Treaties, 7 July 1994). The Netherlands, as a monist country, has a rather unique system in which Parliament can also approve tacitly of treaties. See Fleuren, supra note 42 . This, however, was hardly the case here.

${ }^{69}$ STUDIE- EN INFORMATIECENTRUM MENSENRECHTEN, RATIFICATIE . . . EN DAN? (Ratification, What's Next...) (2012); STUDIE- EN INFORMATIECENTRUM MENSENRECHTEN, AANVULLEND RAPPORT: RATIFICATIE . . EN DAN? (Ratification, what's next ...Additiona Report) (2012); J.M. DE JONG ET AL., ECONOMISCHE GEVOLGEN VAN RATIFICATIE VAN HET VN VERDRAG HANDICAP (Economic consequences of the CRPD) (2013).

70 The Dutch Wet Gelijke Behandeling op Grond van Handicap en Chronische Ziekte (Equal Treatment Act concerning Disabilities and Chronic Illnesses), WGBH/CZ (2003) covered equal treatment pertaining to education, labor, housing and public transport, but had to be amended to include goods and services. The Kieswet (Electoral Code) of 1989 had to be amended to enable access to the voting booth and wider electoral processes. Note that this goes against the rather simplistic view of treaty ratification within monist systems and shows the blurred line between monist and dualist systems.

${ }^{71}$ Rijkswet van 14 April 2016, Houdende Goedkeuring van het op 13 December 2006 te New York tot Stand Gekomen Verdrag Inzake de Rechten van Personen met een Handicap (Law of Approval of the CRPD) (Trb. 2007, 169 en Trb. 2014, 113), STAATSBLAD 2016, 182.

72 AusT, supra note 34, at 205-27.

${ }^{73}$ Oud-Kamerlid Otwin van Dijk Over de Rechten van Gehandicapten (Former Parliamentarian Otwin van Dijk on Disability Rights), UWV PERPECTIF, available at https://perspectief.uwv.nl/artikelen/oud-kamerlid-otwin-van-dijk-over-de-rechten-vangehandicapten.

${ }^{74}$ CRPD, supra note 51, art. 9, II 1.

${ }^{75}$ CRPD, supra note 51, art. 9, II 2(b). 
${ }^{76}$ Memorie van Toelichting, Tweede Kamer, Vergaderjaar 2013-2014, 33992 (R2034), nr. 3 (Explanatory Memorandum).

77 These only concern motions that were adopted. The government was asked to pay attention to these issues in the respective motions: Motion of the members Bergkamp and Voortman, Parliament, Vergaderjaar 2015-2016, 33 990, nr. 52; Motion of the member Keijzer, Parliament, Vergaderjaar 2015-2016, 33 990, nr. 41; Motion of the member Otwin van Dijk, Parliament, Vergaderjaar 2015-2016, 33 990, nr. 40; Motions of the members Voortman and Otwin van Dijk, Parliament, Vergaderjaar 2015-2016, 33 990, nr. 44; Nader Gewijzigd Amendement (Amendment adjusted again) of the members van der Staaij and Bergkamp to replace what was stated under nr. 19, Parliament, Vergaderjaar 2015-2016, 33 990, nr. 35; Uitvoering Verdrag Inzake de Rechten van Personen met een Handicap (Implementation CRPD), Parliament, Vergaderjaar 2015-2016, 33 990, nr. 36-10. All of these motions were adopted during the CRPD proceeding in Parliament. Other issues addressed in motions but not discussed here are attention for the CRPD in foreign policy, sexuality, disabilities, and assistance dogs.

${ }^{78}$ Brief van de Staatssecretaris van Volksgezondheid Welzijn en Sport (Letter of the State Secretary of Public Health, Wellbeing and Sports), Tweede Kamer, Vergaderjaar 2015-2016, 33 990, nr. 25 [hereinafter Letter of the State Secretary of Public Health, Wellbeing and Sports, nr. 25]. Similar examples were given by the government in earlier stages of the parliamentary proceedings.

${ }^{79}$ Alle Gebouwen Toegankelijk Voor Gehandicapten, ALGEMEEN NEDERLANDS PERSBUREAU ANP, 21 Jan. 2016 (All buildins accessibile for people with disabilities, quoting O. van Dijk).

${ }^{80}$ Ontwerp-Besluit van Houdende Regels Omtrent de Algemene Toegankelijkheid Voor Personen met een Handicap of Chronische Ziekte (Besluit Toegankelijkheid Voor Personen met een Handicap of Chronische Ziekte) (Provisional Decision on Rules Pertaining to General Accessibility for People with a Disability or Chronic Disease) 4 (7 Nov. 2016), available at https://www.internetconsultatie.nl/toegankelijkheid.

${ }^{81} I d$.

${ }^{82} \mathrm{See}$, for instance, the response of the main NGO coalition, COALITIE VOOR INCLUSIE, available at https://coalitievoorinclusie.nl/encyclopedia/besluit-toegankelijkheid/; see also TWITTER, available at www.twitter.com (searching hashtags \#jekomternietin (\#youwillnotgetin) and \#jekomternooitin (\#youwillnevergetin)).

${ }^{83}$ Letter of the State Secretary of Public Health, Wellbeing and Sports, nr. 25], supra note 9.

${ }^{84}$ Besluit van 7 juni 2017, houdende regels omtrent de algemene toegankelijkheid voor personen met een handicap of chronische ziekte (Besluit toegankelijkheid voor personen met een handicap of chronische ziekte) (Decision on Rules Pertaining to General Accessibility for People with a Disability or Chronic Disease, 7 June 2017).

${ }^{85}$ Ida Elizabeth Koch, From Invisibility to Indivisibility: The International Convention on the 
Rights of Persons With Disabilities, in THE UN CONVENTION ON THE RIGHTS OF PERSONS WiTH DisAbilities: EuRoPeAN AND SCANDinAVian PERSPECTIVES 67, 73 (Oddný Mjöll Arnardóttir \& Gerard Quinn eds., 2009).

${ }^{86}$ Committee on the Rights of People with Disabilities: Communication No. 4/2011, adopted 9 Sep. 2013, I[ 9.5, CRPD/C/10/D/4/2011 (2013).

${ }^{87}$ Nota Naar Aanleiding van het Verslag, Tweede Kamer, Vergaderjaar 2014-2015, 33992 (R2034), nr. 6 (Memo in response to the report).

${ }^{88}$ Charlotte O'Brien, Driving Down Disability Equality?: Case C-356/12 Wolfgang Glatzel v. Freistaat Bayern, Judgment of 2 May 2014, 21 MAASTRICHT J. EuR. \& COMP. L. 723, 724 (2014); EU Court of Justice: Case C-363/12, Z. v. Govt. Dept., Board of Mgmt. Community School, ECLI:EU:C:2014:159.

${ }^{89}$ Fons Coomans, Some Introductory Remarks on the Jusiciability of Economic and Social Rights in a Compararative Constitutional Context, in JusTiCIABILITY OF ECONOMIC AND SocIAL RIGHTS: EXPERIENCES FROM DOMESTIC SySTEMS 1, 7-9 (Fons Coomans ed., 2006); Frank Vlemminx, The Netherlands and the ICESCR: Why Didst Thou Promise Such a Beautous Day?, in JUSTICIABILITY OF ECONOMIC AND SOCIAL RIGHTS, supra, at 43, 45.

${ }^{90}$ Letter of the State Secretary of Public Health, Wellbeing and Sports, nr. 25], supra note 9.

${ }^{91} I d$.

92 The corrected steno report of the minutes of the meeting on 12 Apr. 2016 (Eerste Kamer, Vergaderjaar 2015/2016 nr. 27), on file with the author.

${ }^{93}$ Brief van de Staatssecretaris van Volksgezondheid, Welzijn en Sport (Letter of the State Secretary of Public Health, Wellbeing and Sports), Tweede Kamer, Vergaderjaar 2015-2016, 33 990, nr. 59. The comment, by Mr. Ganzevoort, is taken from the same report.

${ }^{94}$ For the plans with respect to strategic litigation see: https://www.in1 school.nl/kennisondersteuning/dossier-strategische-procesvoering

${ }^{95}$ CRPD, supra note 51, art. 24(2).

9670 Duizend Basisschoolleerlingen in Speciaal Onderwijs (70.000 Primary School Children in special Needs Education), CBS, 21 July 2014, available at https://www.cbs.nl/nl$\mathrm{nl} /$ nieuws/2014/30/70-duizend-basisschoolleerlingen-in-speciaal-onderwijs (on the basis of the 2013-2014 figures).

${ }^{97}$ Concept by the Ministry, supra note 7.

${ }^{98}$ COALITIE VoOR InClusie, Het VN VERdRAG BEPAALT: INCLUSIEF ONDERWIJS IS EEN RECHT VOOR ALLE KINDEREN! (CRPD: Inclusive Education is a Right for all Children) 21 (2010). 
${ }^{99}$ CoAlitie Voor InClusie, TeKenen EN DAN......?: STUdie: STAND VAN ZAKEN EN AANBEVELINGEN VOOR DE IMPLEMENTATIE VAN HET VN-VERDRAG INZAKE DE RECHTEN VAN PERSONEN MET EEN HANDICAP (Signing and Then......?: Study with Regards to the State of Affairs and Recommendations for the Implementation of the CRPD) (2010).

${ }^{100}$ Wijziging van enkele onderwijswetten in verband met een herziening van de organisatie en financiering van de ondersteuning van leerlingen in het basisonderwijs, speciaal en voortgezet speciaal onderwijs, voortgezet onderwijs en beroepsonderwijs, Memorie van Toelichting, Tweede Kamer, Vergaderjaar 2011-2012, 22 106, nr. 3 (Amendment of several educational laws with regards to a revisal of the organization and financing of support to learners in primary, special, secondary and vocational education).

101 Nota Naar Aanleiding van het Nader Verslag, Tweede Kamer, Vergaderjaar 2014-2015, 33990, nr. 6; (Extra report and memo in response to extra report). Interestingly, the exact same questions are posed by D66 politicians in the extra report as by the PvdA politicians in the response to this report.

${ }^{102}$ Id. p. 35.

${ }^{103}$ Even if parliamentarian Van Dijk did name the term a few times, those were the only moments in Parliament at which CRPD, art. 24(2) was invoked..

104 SARDES, RICHTING EN INRICHTING VAN PASSEND ONDERWIJS IN SAMENWERKINGSVERBANDEN - DEElonderzoek A: STAND VAN ZAKEN SAMENWERKINGSVERBANDEN PASSEND ONDERWIJS PRIMAIR ONDERWIJS EN VOORTGEZET ONDERWIJS (Direction and Implementation of Fitting Education in Educational Cooperations, Partial Research Concering Primary and Secondary Education) (2015). These figures concern primary school directors $(\mathrm{N}=48)$. Where it concerns secondary education, the differences are 100 percent versus 12 percent. The top three of principles named was: the needs of pupils, the expertise of teachers, and a shared vision on the direction to take.

105 This statement is based on a search in the main Dutch legal search engine Kluwer Navigator with the terms "Passend Onderwijs" in combination with "Verdrag" or "Inclusie" or "Gehandicaptenverdrag."

106 The total budget cut involved with the introduction of the WMO was $€ 3$ billion. See Senaat is Doof Voor Kritiek op WMO (The Netherlands Country of Participation? The Ambitions of the Social Support Law and the Practice in Neighborhoods, Support Systems, and Churches), FNV, 9 July 2014, available at https://www.fnv.nl/sector-en-cao/alle-sectoren/zorg-enwelzijn/vvt/nieuws/1063407-senaat-is-doof-voor-kritiek-op-wmo/. M. Vreugdenhil, Nederland Participatieland? De Ambitie van de Wet Maatschappelijke Ondersteuning (Wmo) en de Praktijk in Buurten, Mantelzorgrelaties en Kerken (2012) (dissertation, University of Amsterdam).

${ }^{107}$ F. Agema (PVV) during the parliamentary discussion on the Convention, Tweede Kamer, Vergaderjaar 2015-2016, 3399214 Jan. 2016, 42, item 9, on 42-9-15. 
${ }^{108}$ Contribution N. Vos de Wael (Platform GGZ) to the parliamentary hearing on the CRPD, Tweede Kamer, Vergaderjaar 2015-2016, 33990, nr7, 9 February 2015. 